\title{
Does Australia Have A Good Income Tax System?
}

Anthony Stokes, Australian Catholic University, Australia Sarah Wright, Australian Catholic University, Australia

\begin{abstract}
Australia is considered to have relatively low rates of tax in comparison to other members of the OECD. This paper explores Australia's tax system to see if it is a fair, efficient and simple system for income earners. The paper finds that there are major inequities in the current income tax system, which tend to favour the higher income earners and owners of wealth.
\end{abstract}

Keywords: Taxation; Equity; Efficiency; Simplicity; Australian Policies; Inequality

\section{INTRODUCTION}

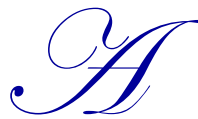

$\mathrm{t}$ a time when many nations are looking at their taxation policies, this paper sets out to review the effectiveness and impact of Australia's taxation policy. Australia has a relatively high top marginal income tax rate of 45 percent $^{1}$, but it does cut in at a relatively low income level of $\$ 180,000$ Australian $^{2}$. In other nations, France is currently considering a top income tax rate of 75 percent on its millionaires and the USA is looking at its marginal income tax rates in light of the challenge of the so called 'fiscal cliff'. In the USA, the top marginal Federal tax rate is 39.6 percent for individual income earners, but it only cuts in when individuals earn over $\$ 400,000$ per annum or $\$ 450,000$ for families.

The Australian Treasury (2010) considers that the development of the Australian tax system can be categorized into two distinct periods. 'In the first period, from federation to the mid-1970s, the focus was largely on revenue adequacy to fund increasing levels of social provision of goods and services. In the second period, since the mid-1970s, there has been a greater focus on improving the equity, efficiency and simplicity of the tax system'. However, despite Australia's continual process of tax reform, the Government (Treasury, 2010 p. XV) argued that the structure of Australia's tax and transfer system needed to be reviewed in order to 'meet the challenges of the $21^{\text {st }}$ century and to enhance its economic and social outcomes'. The key findings of the Henry Review are outlined in the Australian Government's final report titled 'Australia's Future Tax System'. The Australian Council of Trade Unions (ACTU) (2011 p. 4) argued that this tax review provided the opportunity to design a tax system that satisfies 'Australian's needs and preferences and that positions Australia well for the future'. This paper will discuss the principles of a good tax system and the consequences of recent tax reforms.

\section{WHAT IS A 'GOOD’ TAX SYSTEM?}

Even though the Henry Review created a tax forum to raise debate over what principles should underpin Australia's tax system, this debate is not new. The essentials for designing a good tax system have been discussed as early as Adam Smith (1776) in his 'Canons for Taxation'. There is a general consensus among academics that the basic criteria for a good tax system are that it should be fair, efficient and simple.

A fair tax system is one that embraces both horizontal and vertical equity. Horizontal equity asserts that people in similar economic circumstances should be treated equally. In this case, people who earn similar incomes

\footnotetext{
${ }^{1}$ Australian income tax payers are also subject to a 1.5 percent medicare levy. The percentages in this paper exclude that levy.

${ }^{2}$ The Australian dollar at the start of 2013 was slightly above par with the US dollar, \$1 Aust. = \$1.05 US.

2013 The Clute Institute $\quad$ Copyright by author(s) Creative Commons License CC-BY
} 
should pay the same level of tax. Meanwhile, vertical equity refers to those in different economic circumstances being treated differently. This implies that the most able should pay the highest amount of tax (Baumol and Blinder, 2012).

According to the OECD, an efficient tax system is one where the compliance costs for taxpayers and administrative costs for authorities are at a minimum. While many academics refer to similar definitions of efficiency, in this paper, efficiency refers to society gaining the maximum benefits from its scarce resources. That is, resources should be allocated to areas where there is the greatest economic gains and not just to areas that will generate the maximum tax savings to individuals.

Alley and Bentley (2005 p. 622) state that 'tax rules should not be arbitrary'. A simple tax system allows taxpayers to comply with the rules in a cost effective manner. Palil and Mustapha (2011) argue that when a tax system lacks simplicity, it results in a greater number of taxpayers making errors, being non-compliant and disrespecting the system. However, while a simple system implies that it should be comprehensible, it should not be at the expense of achieving equity.

\section{DOES AUSTRALIA HAVE A 'GOOD' INCOME TAX SYSTEM?}

\section{Methodology and Background to the Study}

This study will investigate a variety of data sources from the Australian Bureau of Statistics (ABS), the Australian Taxation Office (ATO), Australian Treasury and the OECD to measure the impact and effectiveness of Australia's taxation system, especially in regards to personal income tax.

According to OECD data (2012), Australia's overall level of tax is relatively low in comparison with other OECD nations. In 2010, Australia's total taxation collections were the fifth lowest out of 34 OECD nations - 25.6 percent of Australia's GDP (see Figure 1). Eslake (2011) argues that the total level of taxation collected by Australian governments is neither insufficient nor excessive and suggests that there is not a compelling case for claiming that Australia has high overall tax levels.

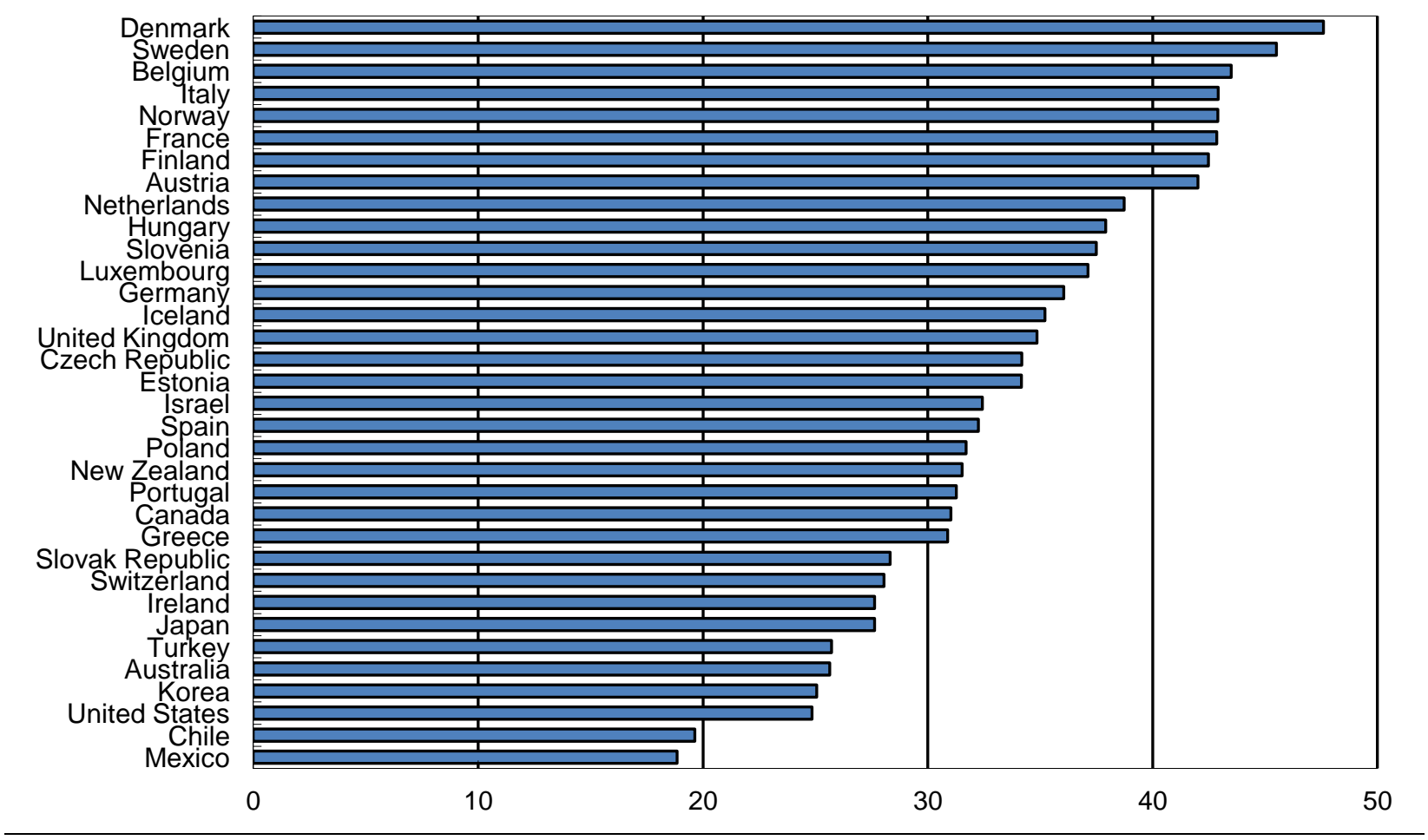

Figure 1: Total Tax Revenue as a Percentage of GDP Source: Adapted from OECD (2012) 
Not only does Australia have a relatively low tax burden, but Australia's overall tax burden (tax as a percentage of GDP) has continued to decline from 30.4 percent in 2000 to 27.1 percent in 2008 to 25.6 percent in 2010 (OECD, 2012). Figure 2 shows that during the period from 1995 to 2010, Australia's tax to GDP ratio declined by 2.5 percentage points.

Although Australia's overall level of tax revenue is relatively low in comparison to other OECD nations, this does not provide evidence to suggest that Australia's tax system is equitable, efficient or simple. Rather, an analysis of the latest tax reforms suggests that Australia's tax system breaches all of these principles. For instance, Australia's tax system is not equitable when different income types are taxed inconsistently and a large proportion of Australia's tax revenue is sourced from wage and salary earners. In 2010, 57.1 percent of Australia's tax revenue was generated from taxes on income and profits. This burden is not only higher than the OECD average of 33.2 percent, but it also represents the second highest burden on wage and salary earners out of all OECD countries, with Denmark the highest at 61.1 percent. More specifically, tax on personal income equates to 38.6 percent of Australia's tax revenue. This has increased from 36.5 percent in 1965 and is higher than the OECD average of 23.9 percent.

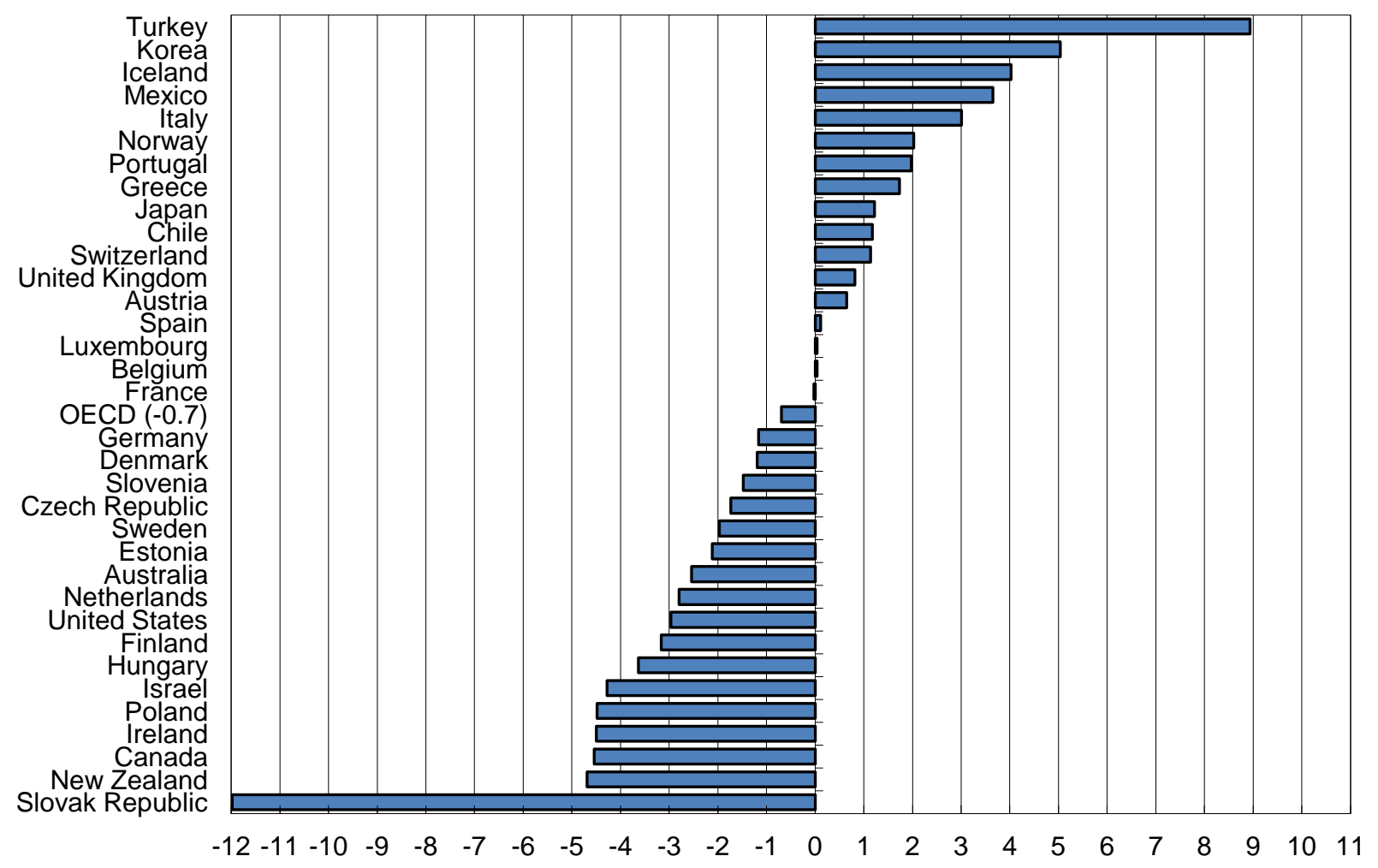

Figure 2: The Changes in Tax to GDP Ratio (in percentage points) 1995-2010

Source: Adapted from OECD (2012)

\section{Is the current income tax system equitable?}

While the Government is committed to upholding a progressive income tax system, there are a number of concerns surrounding the equity of the current tax system. One of these concerns relates to low to middle income earners being disadvantaged through changes in the marginal rate of income tax. As shown in Figure 3, the average income tax rate has increased steadily, yet the top marginal rate of tax has fallen significantly. 


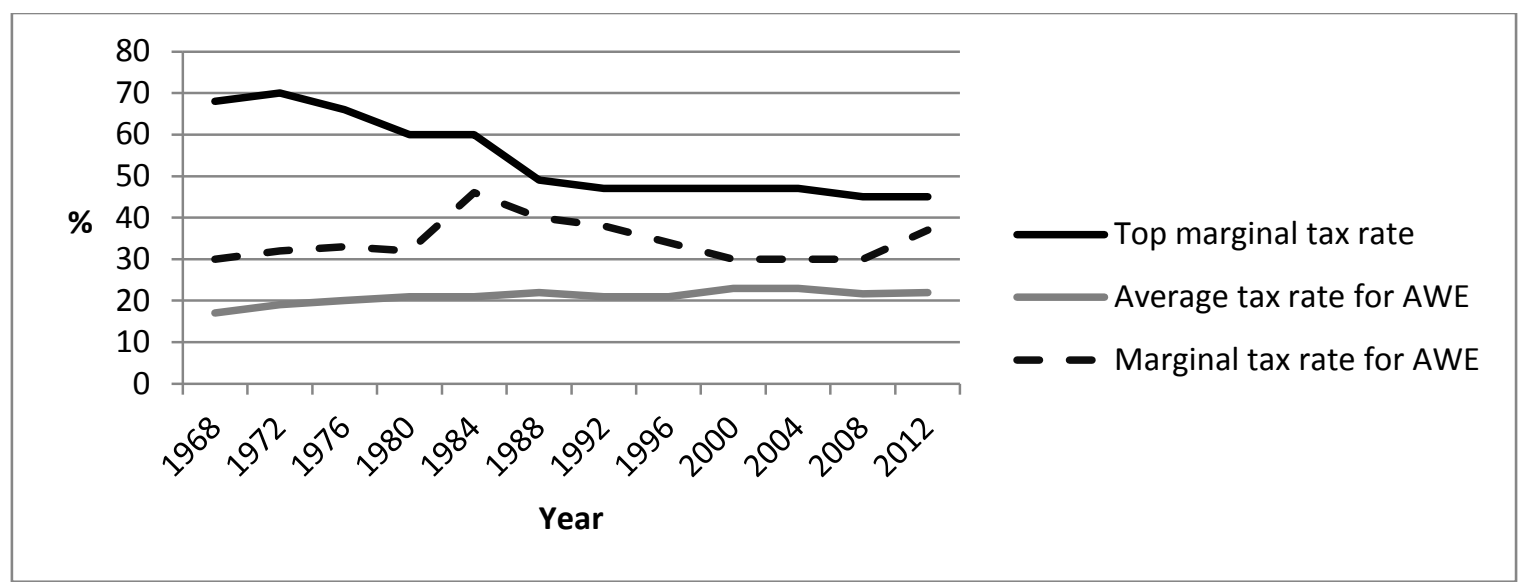

Figure 3: Top, Marginal and Average Rates of Tax for those on Average Weekly Earnings (AWE) Source: Adapted from data from Treasury, 2006, OECD, 2012, ABS, 2012

At the end of 2012, the marginal income tax rate for a person on average weekly earnings (AWE) had risen to 37 percent, while the marginal income tax rate for the highest income earners was only 45 percent. In the period 1968 to 2012, the marginal tax rate for the highest income earners has fallen from 68 percent to 45 percent. At the same time, the marginal tax rate for those on average weekly earnings has risen from 30 percent to 37 percent, while their average tax rate has risen from 17 percent to 22 percent of their income. This not only creates an unfair tax system, but it also creates a disincentive for low to middle income workers to work and undermines the premise for a progressive tax system.

The implications of lowering the top income tax rate can be seen in Figure 4. By lowering the top rate of tax, the income tax liability for those on relatively high incomes is significantly lower under the current system than if the rate of tax had remained at the year 2000 tax level. According to the ACTU (2011), over the last decade those on the average wage have received a real tax cut of $\$ 1,300$; meanwhile, those earning three times the average wage received a real tax cut nearly ten times those on average incomes at $\$ 12,170$.

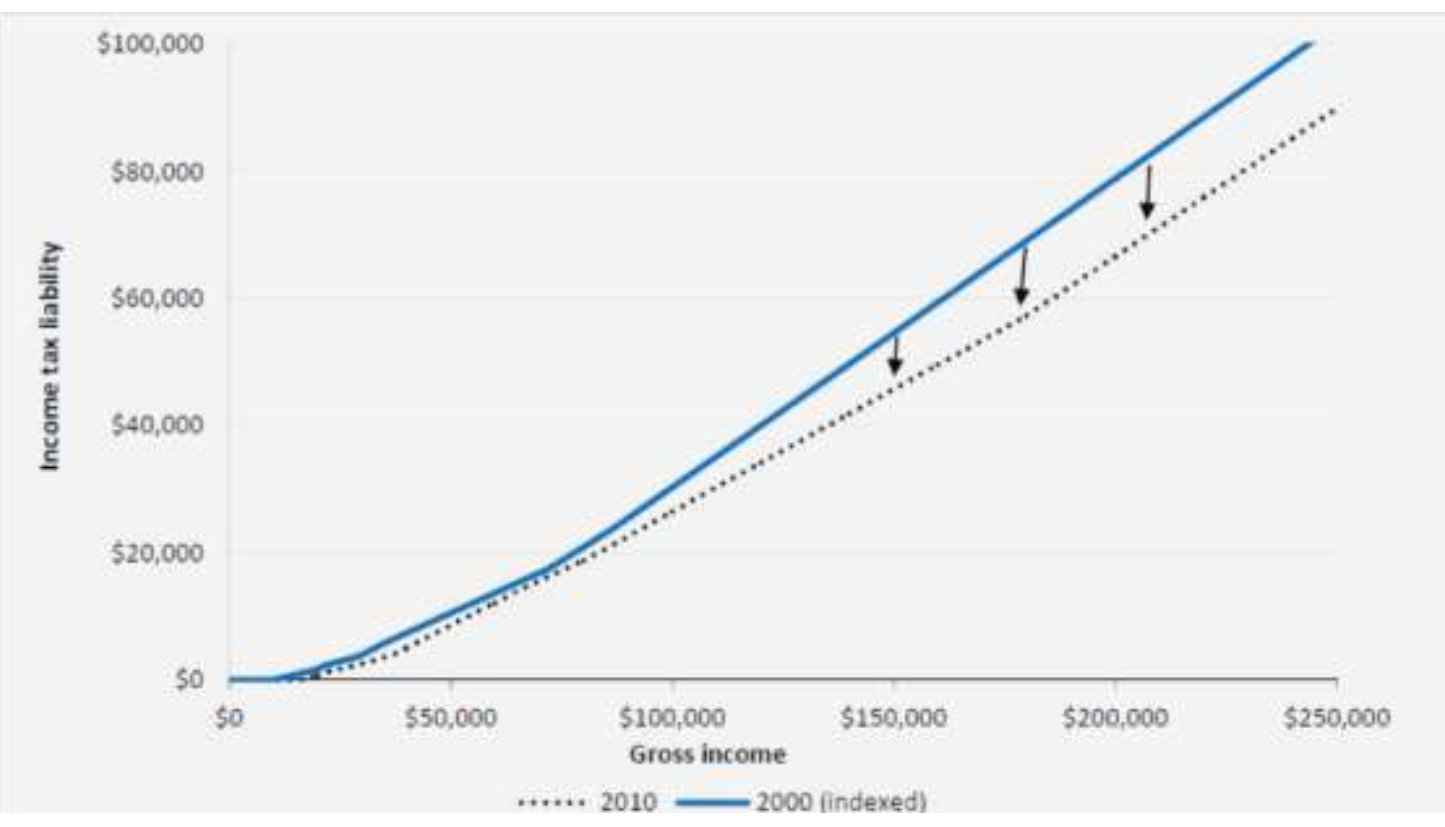

Figure 4: Income Tax Liability for 2000 (indexed) and 2010

Source: ACTU (2011) 
As a tool for restoring equity, the current progressive tax system is further limited by the different treatment of various income sources. Table 1 shows the different effective rates of tax for those earning $\$ 180,000$ or above per annum. Wages, salaries and income from personal savings are charged with the highest rate of tax at 45 percent; meanwhile, a similar level of income generated from investments faces a lower rate of tax at 22.5 percent. Moreover, investments that are funded by debt, such as negative gearing on investment properties, provide a subsidy to reduce the amount of tax payable. This not only creates opportunities for high income groups to avoid paying tax, it also creates an inequitable and inefficient tax system.

Table 1: Effective Tax Rates for High Income Groups $\mathbf{( \$ 1 8 0 , 0 0 0 +}$ per annum)

\begin{tabular}{|l|l|}
\hline \multicolumn{1}{|c|}{ Effective Rate Of Tax } & \multicolumn{1}{c|}{ Income Type } \\
\hline $45 \%$ & Personal earnings or bank interest \\
\hline $22.5 \%$ & Capital gains \\
\hline $15 \%$ & Employer superannuation contribution \\
\hline $15-30 \%$ & Golden handshakes \\
\hline $15 \%$ & Discretionary trust income split with a family member employed part-time \\
\hline Negative & Loss making investment \\
\hline
\end{tabular}

Source: Adapted from Australian Council of Social Service (ACOSS) (2011)

This inequity is reinforced by the findings in the Henry Review which revealed that the main sources of income for the bottom 50 percent of households are wages, salaries and savings, whereas the top 10 percent of households generate their income from a range of sources, including low taxed investments such as trusts, dividends and capital gains (Figure 5).

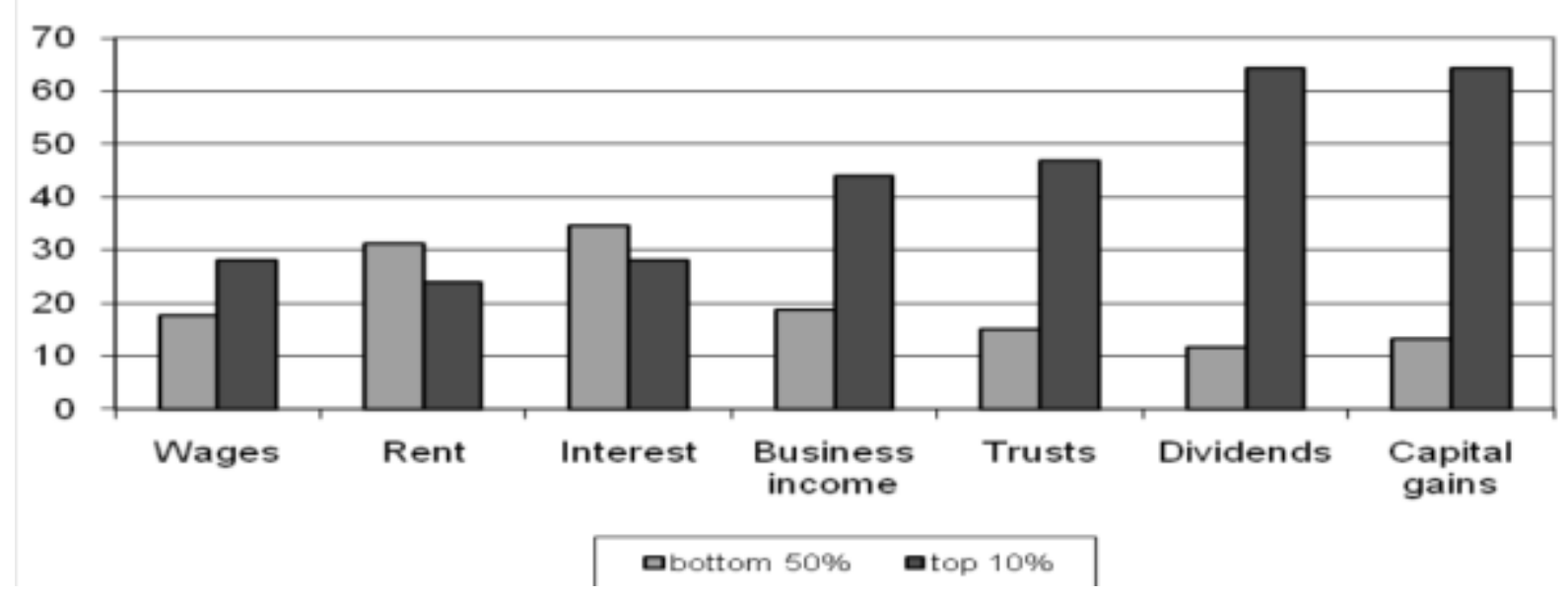

Figure 5: Share Of Income From Different Sources For 2006

Source: Treasury (2008)

The overall effects of these changes are measured by ABS (2012) data on government benefits, taxes and household income. It shows that in the period 2003-04 to 2009-10, the average tax rate for the highest 20 percent of income earners declined from 25.6 percent of gross income to only 20.7 percent. The highest income earners received the biggest percentage reductions as a proportion of gross income.

\section{Tax Rates and the Disincentive to Work}

The Effective Marginal Tax Rates (EMTRs) are useful for measuring both inequity and the disincentive to work. EMTR measures 'the proportion of an additional dollar of earnings that is lost to both income tax and the reduction in income-tested government benefits' (Harding et al., 2009). Under the current progressive tax system, 
low income earners, such as those receiving Newstart ${ }^{3}$ and Youth Allowance, ${ }^{4}$ face an EMTR of 60 percent. That is, they receive 40 cents from each extra dollar they gain from working. However, according to a NATSEM study (Harding et al. 2009), there are a number of low income Australians who face an EMTR greater than 50 percent, not just those receiving Newstart and Youth Allowance. In fact, Harding et al. (2009) found that the proportion of low income earners who face an EMTR of 50 percent has increased from 4.8 percent in 1996-97 to 7.1 percent in 200607. This EMTR is greater than the 45 percent marginal rate of tax paid by high income earners. This is not only unfair; it also creates a disincentive for people to work, especially women with children. As can be seen in Figure 6, if a secondary income earner receives an income of $\$ 800$ per week, they lose 65.5 percent of any additional income in tax. This is a considerable disincentive to work more hours. The tax rate does drop, eventually, if the person earns in excess of $\$ 1,000$ per week.

The progressive tax system in Australia is also limited by the level of tax avoidance and minimization largely conducted by higher income earners. Denniss (2008) points out that 5,600 business executives earned over $\$ 1$ million in 2006, yet they all paid less than 20 percent of their income in tax. This was the same rate of tax as a person who earned an annual income of $\$ 30,000$ and less than the 30 percent tax rate faced by those earning $\$ 60,000$ per year.

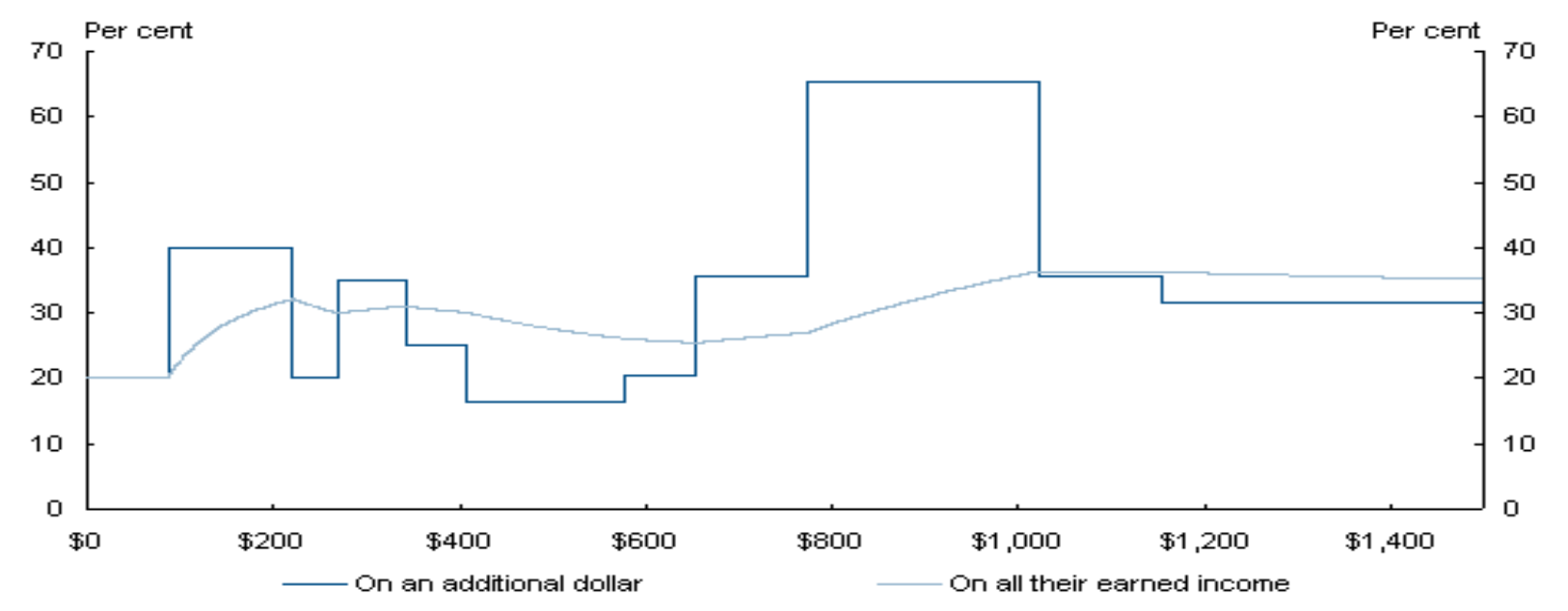

Figure 6: Effective Tax Rates for a Secondary Income Earner with Two Children Aged 6 and 7 Years Source: Treasury (2008)

Not only can higher income earners avoid paying tax, they can also receive a subsidy from the Government to reduce the amount of tax payable. They can do this through negative gearing. According to Eslake (2011), in 1998-99 when capital gains was taxed at the same rate as other incomes, 1.3 million landlords received a taxable profit of $\$ 700$ million. However, since then, capital gains tax has been reduced to 22.5 percent (half the 1998 tax rate). There are 1.7 million landlords who claimed to have made a combined loss of $\$ 6.5$ billion. Under the current system, if interest on borrowings used to finance the property exceeds the rent, then the excess can be deducted against the taxpayer's income. Therefore, the loss of $\$ 6.5$ billion was the result of interest rising four-fold, but rent only doubling. Eslake (2011) argues that if these landlords were in the 38 percent income tax bracket, they would have cost the government $\$ 4.3$ billion, and if 20 percent had been in the top tax bracket, $\$ 4.6$ billion in revenue would have been lost.

\footnotetext{
${ }^{3}$ Newstart Allowance is a payment by the Australian Government to encourage job seekers to undertake activities, such as training, to increase the unemployed persons' chances of getting a job.

${ }^{4}$ Youth Allowance is a payment by the Australian Government for young people who are studying full-time, undertaking a fulltime Australian Apprenticeship, training, looking for work, or sick.
} 


\section{The Impact of Indirect Taxes}

Not only do recent statistics suggest that low income earners face relatively higher EMTRs compared to high income earners and gain the least from low tax investments, they are also more adversely affected by the GST. The GST - a goods and services tax - was introduced in the year 2000 as a solution to the existing cumbersome and irrational indirect tax system. Advocates of the GST argued it would increase efficiency as it taxes all goods and services at the same rate (10 percent). However, this regressive tax system places the heaviest burden on those with fixed to low incomes. This is because those on lower incomes pay a higher percentage of their income on the GST and, unlike higher income earners, they do not benefit from the tax reductions associated with the abolition of higher sales taxed on luxury items. ABS (2012) data on government benefits, taxes, and household income shows that the indirect tax system in Australia continues to be regressive with the poorest 20 percent of households paying 17 percent of their income in indirect taxes compared to 9 percent for the richest 20 percent of households in 2009-10.

As can been seen in Figure 7, the third largest source of government tax revenue for 2011-12 was sales tax at 15.5 percent of total tax revenue. Figure 8 shows that since the year 2000, sales taxes increased significantly as a consequence of the GST. This suggests that the government is relying heavily on tax revenue from both income tax and the GST, which impose a large burden on low income earners.

While advocates of the GST argue that low income earners are protected by provisions such as the exemption of GST on basic food items, the Henry Review (Treasury, 2010) found that those on higher incomes spent six times as much on GST-free food items than those on relatively low incomes. That is, over one-third of the $\$ 5$ billion revenue forgone on GST-free food goes to the highest 20 percent of income earners.

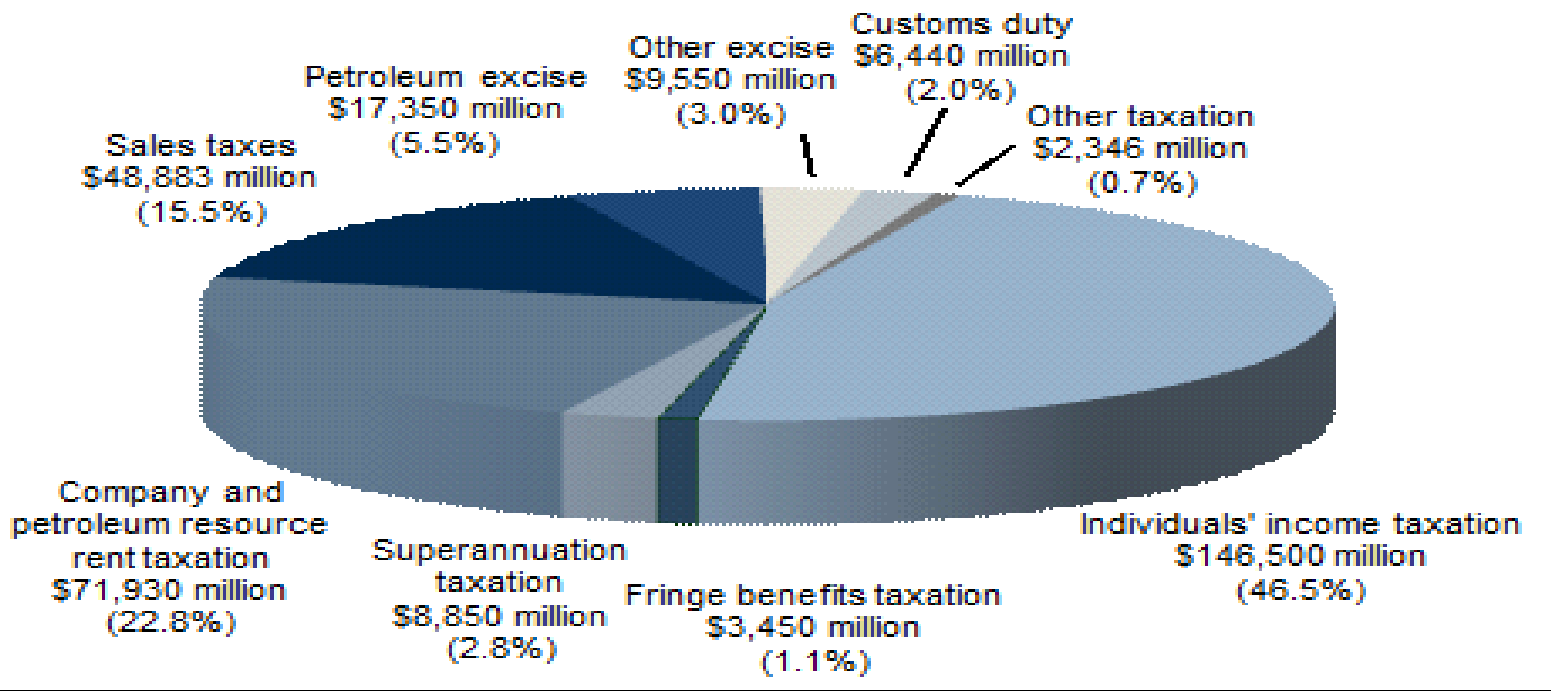

Figure 7: Australian Government Tax Mix for 2011-12

Source: (Treasury, 2012)

Not only is the GST highly regressive, it is also relatively expensive to administer. According to Eslake (2011), it costs the Australian Taxation Office (ATO) approximately 94 cents per $\$ 100$ of revenue to collect most taxes. However, when the ATO collects the GST, it costs $\$ 1.36$ per $\$ 100$ revenue. 


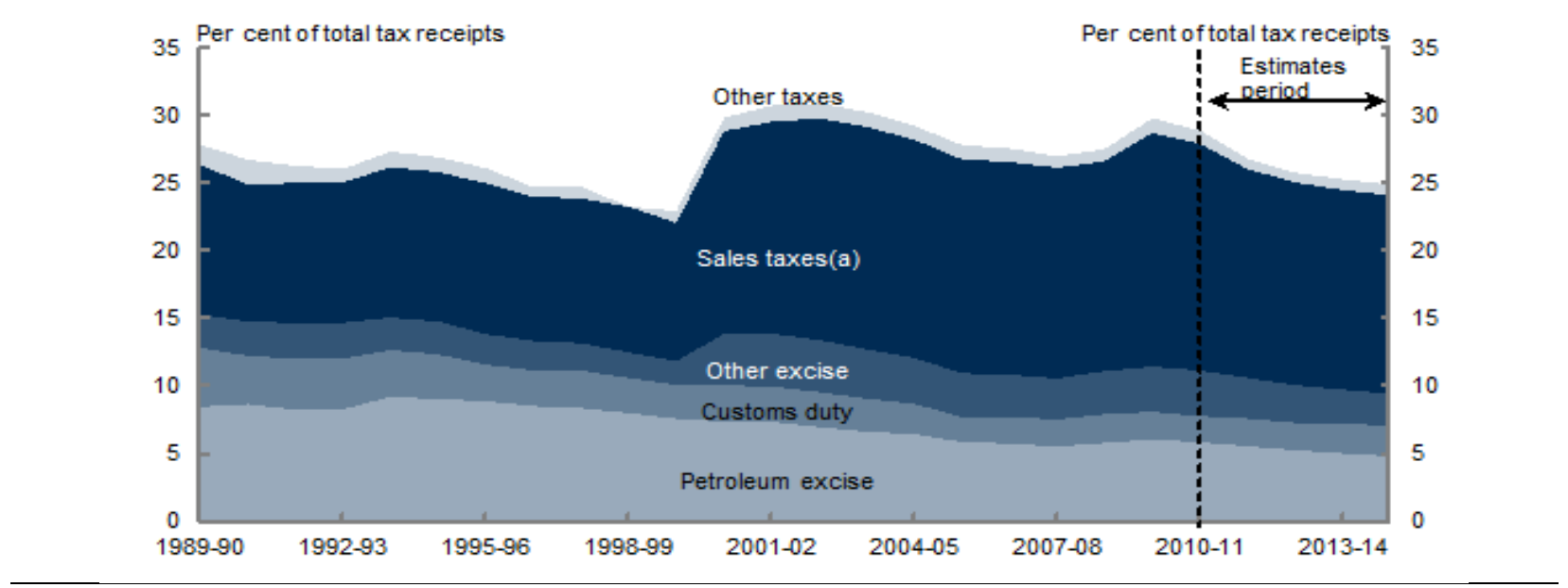

Figure 8: Australian Government Indirect Taxes

Source: (Treasury, 2012)

\section{Is the Australian Income Tax System Simple to Understand and Apply?}

In addition to Australia's tax system being inequitable and inefficient, it also lacks simplicity. This lack of simplicity can be seen in the current tax system containing more than 125 taxes and the underpinning legislation known as the Income Tax Assessment Act of 1997 comprising 351 pages (Treasury, 2008; Commonwealth Government, 2012). According to a global survey of tax professionals by the Association of Chartered Certified Accountants (ACCA, 2008), Australia's tax system is ranked the highest in 'complexity' and second lowest in 'fairness'. This is supported by the OECD (2005) study which found that seven out of 10 Australians use a tax agent. As shown in Figure 9, this is the second highest out of the 22 OECD countries surveyed. Eslake (2011) argues this is because Australians feel they cannot comply with the current tax system without a tax agent. Despite more than 70 percent of Australians using a tax agent, 86 percent of these either claim no deductions at all or only claim workrelated expenses.

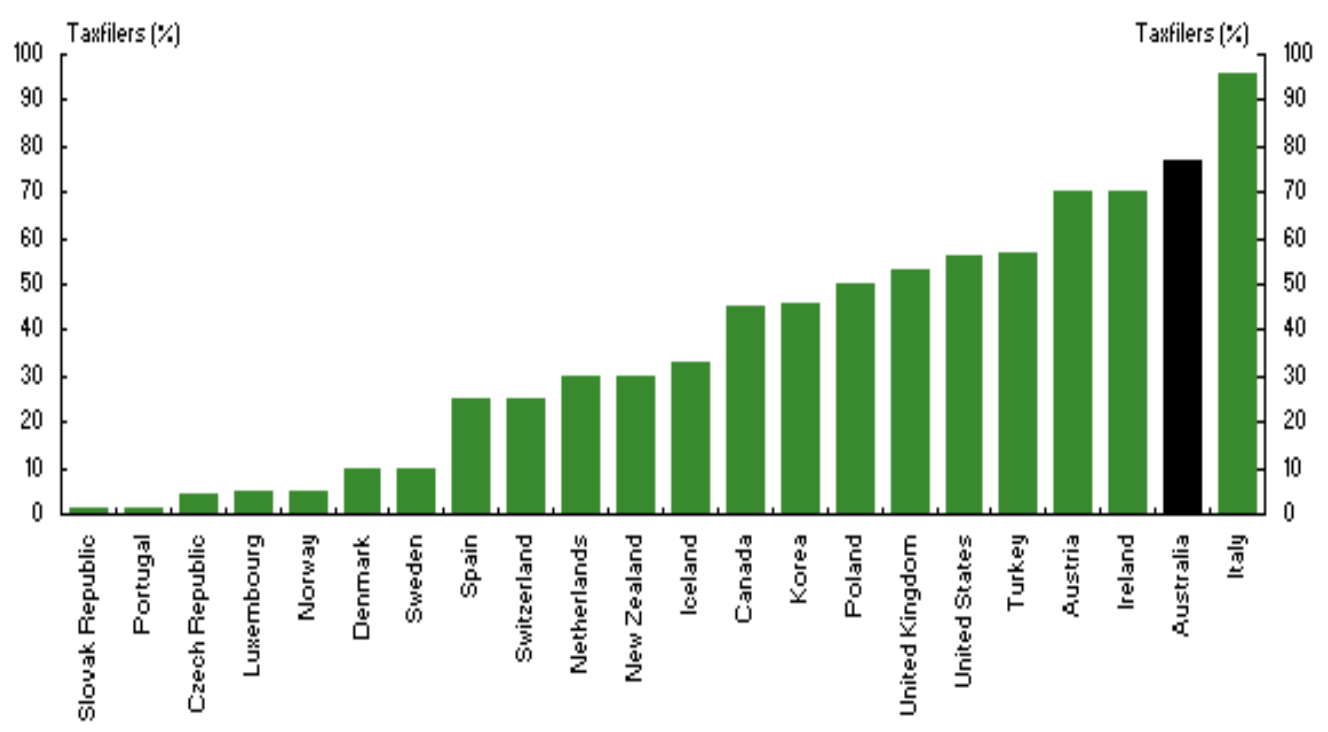

Figure 9: Percentage of Tax Filers Using an Agent Source: OECD (2005) 


\section{WHAT ARE THE ALTERNATIVES?}

Between 2003-04 and 2009-10, the share of final income for the richest 20 percent of households in Australia rose from 33.4 percent to 35.1 percent, while the share of final income for the poorest 20 percent fell from 10.9 percent to 10.3 percent (ABS, 2012). Income inequality is widening. This paper has highlighted a number of the reasons for the widening level of income inequality.

The first issue to consider is the marginal income tax rates. The Australian income tax system needs to become more progressive not less. The tax brackets need to be widened and the top marginal tax rate needs to be increased for the highest income earners (Table 2). Workers on average weekly earnings should not have a marginal tax rate in excess of 30 percent. Incomes triple that of average weekly earnings should determine the basis for a 45 percent tax rate $(\$ 240,000)$ and the highest marginal tax rate of 50 percent should occur around $\$ 500,000$ or six times average weekly earnings. It would be necessary to index these tax rates annually to ensure equity.

Table 2: Australian Marginal Tax Rates 2012-13 and Proposed Levels

\begin{tabular}{|l|l|l|l|}
\hline Taxable Income 2012-13 & \multicolumn{1}{|c|}{ Tax On This Income } & \multicolumn{1}{|c|}{$\begin{array}{c}\text { Taxable Income } \\
\text { (Proposed) }\end{array}$} & \multicolumn{1}{c|}{ Tax On This Income } \\
\hline $0-\$ 18,200$ & Nil & $0-\$ 20,000$ & Nil \\
\hline$\$ 18,201-\$ 37,000$ & $19 \mathrm{c}$ for each $\$ 1$ over $\$ 18,200$ & $\$ 20,000-\$ 50,000$ & $20 \mathrm{c}$ for each $\$ 1$ over $\$ 20,000$ \\
\hline$\$ 37,001-\$ 80,000$ & $\begin{array}{l}\$ 3,572 \text { plus } 32.5 \mathrm{c} \text { for each } \\
\$ 1 \text { over } \$ 37,000\end{array}$ & $\begin{array}{l}\$ 50,001-\$ 100,000 \\
\$ 50,000 \text { plus } 30 \mathrm{c} \text { for each } \$ 1 \text { over }\end{array}$ \\
\hline $\begin{array}{l}\$ 17,547 \text { plus } 37 \mathrm{c} \text { for each } \$ 1 \\
\text { over } \$ 80,000\end{array}$ & $\$ 100,001-\$ 240,000$ & $\begin{array}{l}\$ 21,000 \text { plus } 37 \mathrm{c} \text { for each } \$ 1 \text { over } \\
\$ 100,000\end{array}$ \\
\hline $\begin{array}{l}\$ 54,547 \text { plus } 45 \mathrm{c} \text { for each } \$ 1 \\
\text { over } \$ 180,000\end{array}$ & $\$ 240,001-\$ 500,000$ & $\begin{array}{l}\$ 72,800 \text { plus } 45 \mathrm{c} \text { for each } \$ 1 \text { over } \\
\$ 240,000\end{array}$ \\
\hline & & $\$ 500,001$ and over & $\begin{array}{l}\$ 189,800 \text { plus } 50 \mathrm{c} \text { for each } \$ 1 \text { over } \\
\$ 500,000\end{array}$ \\
\hline
\end{tabular}

The second consideration is to reduce the tax minimization schemes and procedures favoring the highest income and wealth owners. The schemes discussed in Table 1 favor the rich over the poor. Reducing the levels of reductions claimable for capital gains, family trusts, superannuation, and negative gearing would restore some of the equity and progressive nature to the income tax system in Australia.

The third consideration is to reduce the disincentive of the current income tax system for certain relative low income earners, as discussed earlier, in regard to effective marginal tax rates (EMTRs). Social security payments (such as Newstart and Youth Allowance) are typically withdrawn at 60 cents on the dollar. For each additional dollar that a social welfare payment recipient earns from work, they lose 60 cents of their payment. The ACTU (2011) reports that it is this steep 'taper rate' that is the main source of the participation disincentives that are faced by low-income earners. People are more likely to work, or to seek additional work, if they keep a larger proportion of an extra dollar they earn. Studies by the ACTU (2011) report that the size of this behavioral response to marginal tax rates is close to zero for higher income earners; however, low-income earners are particularly responsive to changes in their net incomes. The ACTU (2011) recommends that the most effective approach to this issue is to increase the tax-free threshold and progressive reform of the social security system to prevent high effective EMTRs for low to middle income earners.

There are other alternatives for improving the equity of Australia's tax system by applying wealth and resource taxes, but again, there is often scope for avoidance in such schemes. In terms of Australia's income tax system, the above suggestions are at least likely to provide some improvement in the current system.

\section{CONCLUSION}

It is widely accepted that the basic criteria for a good tax system is that it should be fair, efficient, and simple. This study shows that Australia's tax system does not satisfy these basic criteria. Australian businesses and individuals spend considerable time and resources fulfilling the requirements of the Australian Tax Office to be 
compliant in paying taxes. The GST is unquestionably a regressive tax, while the personal income tax system designed to be progressive - is undermined by tax avoidance and tax minimisation schemes. There is considerably more scope for the higher income earners to minimise their tax liabilities compared to ordinary wage and salary earners.

This paper provides some suggestions to improve the equity of the current income tax system in Australia by changing the marginal rates of income tax and the income tax thresholds. It also proposes a reduction in the tax minimisation benefits associated with schemes that favour the rich over the poor. Finally, this paper suggests ways to reduce disincentives to work, caused by high EMTRs, in order to encourage greater labour force participation by low to middle income earners and those marginally in the labour force.

\section{AUTHOR INFORMATION}

Dr Anthony Stokes is a senior lecturer in economics at the Australian Catholic University, Sydney, Australia. He has written extensively in the areas of contemporary economic policy, school and higher education policy and curriculum. Tony has also been awarded a number of teaching awards and citations. E-mail: tony.stokes@acu.edu.au (Corresponding author)

Dr Sarah Wright is a lecturer in economics at the Australian Catholic University, Sydney, Australia. She has written extensively in areas of contemporary economic policy, and Australia's labor market and higher education policies and has been awarded a number of teaching awards and citations. E-mail: $\underline{\text { sarah.wright @ acu.edu.au }}$

\section{REFERENCES}

1. ACOSS. (2011). A fairer, more efficient tax and social security system. Sydney: ACOSS. Retrieved from: http://acoss.org.au/images/uploads/A_fairer_more_efficient_tax_and_social_security_system_Sept 29_2011.pdf

2. ACTU. (2011). Paving our way. Personal income tax in Australia. Melbourne: ACTU. Retrieved from: http://www.actu.org.au/Images/Dynamic/attachments/7488/ACTU Tax Paper_4 Paying_Our_Way.pdf

3. Alley, C. and Bentley, D. (2005) A remodelling of Adam Smith's tax design principles. Robina: Bond University. Retrieved from: http://epublications.bond.edu.au/law_pubs/45

4. $\quad$ Australian Bureau of Statistics. (2012), Government benefits, taxes and household income. Cat No 6537.0. Canberra: ABS.

5. Baumol, W. and Blinder, A. (2012). Economics principles and policy. $12^{\text {th }}$ ed. Ohio: Cengage Learning.

6. Denniss, R. (2008). The case for a new top tax rate. Canberra: The Australia Institute. Retrieved from: http://www.tai.org.au/file.php?file=rp58.pdf

7. Eslake, S. (2011). Australia's tax reform challenge. Australian Parliamentary library lecture. Parliament house, Canberra. $21^{\text {st }}$ September. Melbourne: Grattan Institute.

8. Harding, A. Vu, Q. Payne, A. and Percival, R. (2009). Trends in Effective Marginal Tax Rates in Australia from 1996-97 to 2006-07. The Economic Record, 85 (271) 449-461.

9. OECD. (2005). Survey of trends in taxpayer service delivery using new technologies, Centre for Tax Policy and Administration, Forum on Tax Administration. Paris: OECD.

10. OECD. (2012). OECD tax revenue statistics 2012. Paris: OECD. Retrieved from: http://www.oecd.org/ctp/taxdatabase

11. Palilm, M. and Mustapha, A. (2011). Determinants of Tax Compliance in Asia: A Case of Malaysia. European Journal of Social Sciences, 24 (1) 7-32.

12. Smith, A. (1776). The wealth of nations. Edited with an introduction and notes by E. Cannan. 1994. New York: Random House.

13. Treasury. (2006). International comparison of Australia's taxes. Canberra: Commonwealth Government.

14. Treasury. (2008). Australia's future tax system. Architecture of the tax and transfer system. Canberra: Commonwealth Government.

15. Treasury. (2010). Australia's future tax system. Final report. Canberra: Commonwealth Government.

16. Treasury. (2012). Pocket guide to the Australian taxation system. Canberra: Commonwealth Government. 